\title{
Analysis of Going Concern Audit Opinion Issuance
}

\author{
Agustina Cahyaning Wibowo* \\ Airlangga University.Jl. Airlangga No. 4, Airlangga, Gubeng, Surabaya, East Java
}

*Corresponding Author: Agustina Cahyaning Wibowo, Airlangga University.Jl. Airlangga No. 4, Airlangga, Gubeng, Surabaya, East Java

\begin{abstract}
Audit Opinion is a communication between auditors and financial statements users. One of the audit opinion types is going-concern opinion. The opinion contains information that the auditor has doubts over the sustainability of a company. The purpose of this study is to analyze the effect of the going concern opinion to stock trading volume. This study is using non - statistical parametric Wilcoxon Signed Rank test. The results showed that there are no differences in trading volume activity, before and after the audit opinion issued. This caused bythe investor who did not analyze financial statements thoroughly and rely on stock prize to do the investment. There are also a variety of psychological factors that influence the decision making of investors.
\end{abstract}

Keywords: Audit Opinion, Going Concern opinion, Trading Volume Activity.

\section{INTRODUCTION}

Financialstatement is the medium of communication between management and financial statements users. To obtain the reliability of a financial statement, it is necessary to audit the financial statements (Laktifaresti, 2012: 1). Audit of financial statements is done so that users obtain reliable information and can be analyzed, making it easier for investors to consider an investment decision.

The results of the audit of financial statements is in the form of opinions. The opinion contains a statement of the auditors that the company's financial statements in accordance with generally accepted standard.

Opinions is to measure a company's prospects in the future and analyze the performance of the company during the period of one year. The audit opinion is to assure investors that the financial statements are relevant.

The existence of a business entity in the long-term economic environment has the objective to maintain the continuity of its businesses, through the assumption of going concern (Warnida, 2011). Sustainability of a company is generally associated with the ability of management to manage the company's resources. When economic conditions become uncertain, investors expect that the auditor gives an early warning of failure of the company (Chen and Church 1996).

The audit opinion can be one of the important considerations for investors in making decisions. If the opinion announce information, it is expected that the market will be in action at the time of the announcement spread in the market (Winarto, 2014). According to Mulyadi (2002: 12), the audit opinion can be used by the auditor to communicate with people in their environment. It shows that the information contained in the auditor's opinion may be used various parties with an interest in the company.

According to Standar Profesional Akuntan Publik(SPAP), there are five types of audit opinion, namely; Unqualified Opinion, an unqualified opinion with an explanatory paragraph, Qualified Opinion, Desclaimer Opinion, and Adverse Opinion.

Unqualified Opinion is the audit opinion opinions are generally issued by a public accountant. This opinion contains information about company's conditions that has been running well. In certain circumstances, the auditor can release an unqualified opinion with an explanatory paragraph. Going concern audit opinion is an audit opinion with an explanatory paragraph. Going concern audit opinion given by the auditor in consideration of doubts regarding the company's ability to sustain the business (SPAP 2011 section 341). 
According to the theory of signal, the content of the information in the audit opinion may influence investor decisions. According Purba (2010), going concern audit opinion could influence investors' views on the performance of the company. This opinion will raise doubts in investors investment decisions. Inclusion of a description of the condition of the company is considered as a 'warning' to the readers of the financial statements of the company's financial condition (Purba, 2009: 78). Therefore, this opinion is regarded as bad news that could affect the stock market reaction. The reaction reflected through changes in the volume of stock trading.

There are two types of stock analysis approach that investors do before making an investment decision which are fundamental approach and technical approach. Based on this, Yoachim dkk (2001) in Natapura (2009) classifies investors in the capital market into three categories based on the behavior of decision-making, namely Investor Intuition, Emotional Investor, and Rational Investor. This study assumed that every investor is rational investor. Investors analyze various risks to stay in a safe and controlled conditions and to prevent the risk that investors may incur losses in the future.

There are various studies to measure the content of the audit opinion in the capital markets. One of these studies is conducted by Chen and Church (1996), which examines the relationship between going concern audit opinion and market reaction to the bankruptcy prediction. The study concluded that opinion going concern could predict bankruptcy, and will reduce the shock on the prediction of corporate bankruptcy. The conclusion of this study indicates that the going concern audit opinion has information for the market.

Ittonent (2007) studied the effect of going concern audit opinion on the reaction of the market, and the effect of agency costs on the degree of acceptance of going concern opinion. The study concluded there is a negative reaction to abnormal returns around the date of publication of audit going concern opinion. It concludes that the going concern opinion does not contain information that affect the market.

Meiden (2008) studied the effect of an unqualified auditor's opinion and unqualified auditor's opinion with an explanatory paragraph to the return and trading volume of shares in non-manufacturing industries listed on the BEJ. The result shows that an unqualified auditor's opinion effects the returns stock and the real estate group, while it does not impact the group of banks and securities. But an unqualified auditor's opinion does not affect the overall trading volume as well as a group of banks, real estates and securities. In addition, the test also showed that an unqualified auditor's opinion with an explanatory paragraph does not affect returns stock and trading volume in whole or group of banks, real estates and securities.

Wicaksono (2011) studied the effect of an unqualified auditor's opinion and a qualified auditor's opinion on the abnormal return. That study concluded that there is no significant influence of an unqualified audit opinion with explanatory paragraph and a qualified audit opinion on the abnormal return.

Laksitafresti (2012) investigated the influence of the effect of unqualified audit opinion with an explanatory paragraph and a qualified audit opinion on the abnormalreturn. The study concluded that there was no significant difference in the share price which was measured by the average abnormal return before and after the announcement of the audit opinion, but there were significant differences in the volume of stock trading before and after the announcement of the audit opinion.

The problems of this study is whether there are differences in the volume of stock trading before and after the issuance of going concern audit opinion.

Brigham and Houston (2010: 40) states that the sign is an action taken by the company's management to provide guidance to investors regarding the company's condition. Instructions is in the form of the information published by the investor. Going concern audit opinion is one of the instructions issued by the management of the company. This opinion considered as a bad sign, because it provides information about bankruptcy in the near future for the company.

Going concern audit opinion provides awareness of investors to the sustainability of the company. Going concern audit opinion reflects the decreasing performance of the company. It can reduce the interest of investors to invest in stocks securities. Decreased interest of the investors can be seen from investor reaction that reflected in the volume of stock trading. Trading volume reflects changes in the expectations of investors. Based on the description above, the hypothesis can be formulated as follows:

$\mathrm{H}_{0:}$ There is no difference in the volume of stock trading before and after the issuance of going concern audit opinion. 
$\mathrm{H}_{1:}$ There are differences in the volume of stock trading before and after the issuance of going concern audit opinion.

\section{METHODS}

The population in this research is manufacturing companies listed in Indonesia Stock Exchange from 2014 to 2016. Total population of the company being acquired is 11 companies which published the going concern audit opinion. This is a population study because the sample size is relatively small at less than 30 companies. The data used in this study is the volume of stock trading, the volume of outstanding shares, and data audit opinion.

This study uses a 11-day period of times during which five days before the publication of opinions, the event date, and 5 days after the publication of opinions. Stock price data, stock index and trading volumes are daily data. This study uses a non-parametric Two Related Samples Test (Test two paired samples) and using a statistical test tools of Wilcoxon Signed RankTest.

This study uses data collection techniques of documentation, namely by looking at the existing secondary data in the form of documents or files, writing, as well as the reports contained in the Indonesia Stock Exchange. Research is also done by using literature and publications that related to the research.

To analyze whether there are differences of abnormal return and trading volume of the shares it needs a collection of daily stock trading valume data on each company that was issuing going concern audit opinion during the window period. The next step is to counta trading volume activity (TVA) from each company during the window period. The next step is to calculate the average trading volume activity (XTVA) on day t during the period of before and after the announcement of going concern audit opinion. And then do two paired sample test TVA before and after the issuance of going concern audit opinion (5\% significance level). For decision-making, if each of the hypotheses has probability of more than $0.05, \mathrm{H}_{0}$ is not rejected, but if the probability is less than 0.05 then $_{\mathrm{HO}}$ is not accepted.

Trading Volume Activity (TVA) is the number of shares of companies traded on the stock at any given time. Here are the steps TVA calculation according Jogiyanto (2010):

The equation is as follows:

\section{$\sum$ shares of the traded company at $\mathrm{t}$ time}

$\operatorname{TVA}_{(\mathrm{it})}=\overline{\sum \text { shares of companies listed on the BEI }}$

To determine the market reaction to the company samples get going-concern audit opinion on the company's stock trading volume during the window period is by using the average trading volume activity (XTVA).

The equation used is as follows:

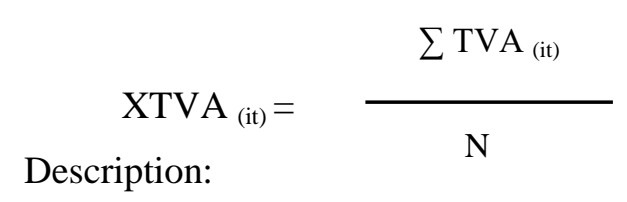

$\mathrm{XTVA}_{(\mathrm{it})}=$ Average trading volume activity stock on day $\mathrm{t}$

$\Sigma \mathrm{TVA}_{(\text {it) }}=$ Total trading volume activity stock on day $\mathrm{t}$

$\mathrm{N}=$ number of samples companies

\section{RESULTS AND DISCUSSION}

The indicator of measuring the reaction of capital markets on the information of going concern audit opinion in this study were trading volume activity (TVA). TVA is calculated by comparing the number of shares of the company traded within a certain period with the total number of outstanding shares of the company at the same time frame. 
Average state TVA daily stock-issuing company going concern audit opinion on the period before and after the date of the announcement event audit opinion is presented in Table 1.

Table1: Average Trading Volume Activity before and after the issuance of going concern audit opinion

\begin{tabular}{|l|l|l|l|}
\hline \multicolumn{4}{|c|}{ Trading Volume Activity } \\
\hline Period & Average & Period & Average \\
\hline-5 & 0,00012637057 & +1 & 0,00007288298 \\
\hline-4 & 0,00009916087 & +2 & 0,00017086161 \\
\hline-3 & 0,00014669852 & +3 & 0,00022770847 \\
\hline-2 & 0,00031563434 & +4 & 0,00009080908 \\
\hline-1 & 0,00016200849 & +5 & 0,00016733012 \\
\hline
\end{tabular}

Based on the above table, it can be seen that the average TVA before and after the issuance of going concern audit opinion is fluctuated. During the observation period, the average TVA is highest in period $t-2$ by 0.00031563434 and the average TVA was lowest in the period $t+4$ for 0.00009080908

During the period prior to the announcement date of the audit opinion report, on average, the highest TVA in period t- 2 by 0.00031563434 and the lowest occurred in period t- 4 of 0.00009916087 . Meanwhile during the period after the date of the announcement of the audit opinion, the highest TVA occurred during the period that is equal to $0.00022770847+3$ and +4 lowest in the period amounted to 0.00009080908 result of hypothesis test for the difference in average trading volume activity before and after the issuance of the going concern audit opinion are as follows:

Table2: Test Results hypothesis average Trading Volume Activity before and after the issuance of audit going concern opinion

\begin{tabular}{|l|l|l|l|c|}
\hline Hypothesis & \multicolumn{1}{|c|}{ Observation Period } & \multicolumn{1}{|c|}{ Significance } & Assymp Sig. (2-tailed) & Result \\
\hline $\mathrm{H}_{1}$ & Before-After & 0.05 & 0.500 & $\mathrm{H}_{1}$ was rejected \\
\hline
\end{tabular}

Table 2 shows the results of non-parametric statistical Wilcoxon Signed Rank Test for a manufacturing company that issued the going concern audit opinion during the observation period 5 days before and after event, with the significance level $\alpha=0.05$ between trading volume activity before and after the issuance of opinions. Based on the table is obtained sig. (2-tailed) of 0.500>0.05 significance level so that $\mathrm{H}_{0}$ is not rejected. This indicates that there is no difference between the stock trading volume before and after the issuance of going concern audit opinion.

Based on the results of hypothesis testing conducted, showed that the going concern audit opinion does not lead to differences in the volume of stock trading $\left(\mathrm{H}_{0}\right.$ and $\mathrm{H}_{1}$ was rejected). This proves that the users of the financial statements did not respond to the content of the information ingoing concern audit opinion. This happens because the audit opinion is the information that appears on an ongoing basis. Investors assume the audit opinion does not reflect the company's performance quality assurance (Widharatna, 2009: 57).

In addition, investors in the Indonesian market is not deeply analyze financial reports and investor ignores information that is considered as a 'warning'. Investors are clearly ignoring the possible risks that would be happened and does not consider the possibility of future losses and retaining investment decisions.

According to Nofsinger (2005) in Triono (2010), investors are likely to use the results in the past as a basis for the evaluation factors or in decision making at the moment. This is one of the psychological factors that influence the decision of investors. Therefore, when the company issued going concern audit opinion, investors did not react to the information.

Their loss information has been obtained by investors before the company received agoing concern audit opinion, this causes the company's value reduction in the eyes of investors. This led to an audit opinion information no longer has a primary value in the eyes of investors.

Based on the period and the profit rate of investment, investors are comprised of long-term investors and short-term investors. Investor behavior thereby causing a difference consideration in making investment decisions. Investors in Indonesia's capital market to do more short-term investments (Suryadi, 2011).

Short-term investors in making investment decisions tend to do a technical approach that took the decision based on the historical stock price charts. This investment does not require a thorough 
analysis of the financial statements, as well as rational reasons in making investment decisions. Shortterm investors believe that fundamental analysis need not be analyzed because all have been counted in the stock price. These investors believe that all the information needed about a stock can be found only in the stock price movement chart.

According to Nofsinger (2005) in Triono (2010), overconfidence can lead investors into overestimate to knowledge and the investor's ability to exercise control over what happens. The behavior of shortterm investors who tend to rely on history chart shows the price of self-confidence. This is another psychological factors that influence investor decisions.

This study is proving to reject the hypothesis because no differences in indicators of stock trading volume before and after the issuance of going concern audit opinion. This indicates that investors do not respond to the audit opinion as one that is consider as a 'warning'. Investors have not been able to anticipate precisely the information that contained ingoing concern audit opinion. Investors decided to invest based on the reference stock price chart movements and does not identify the content of the bad news information that contained in the going concern audit opinion. Immediate past information caused investors to not make an audit opinion as the information has a value in investment decisions.

Lack of knowledge of investors on the capital market and investor confidence factor towards the investment decision that was taken without considering the risks cause changes in the volume of stock trading.

\section{CONCLuSion}

Based on the results of research and discussion that has been done, the study to analyze the differences in the volume of stock trading before and after the issuance of going concern audit opinion has led to the conclusion that there is no difference in the volume of stock trading before and after the issuance of going concern audit opinion because investors did fundamental analysis of stock prices and their information company losses the previous year caused investors to ignore information audit opinion. Several psychological factors also influence the investment decisions of investors.

This study has limitations, including the limited sample size of only 11 companies, the period of observation time is relatively short for eleven days, the diversity of types of investors in the capital markets has led to difficulties of focusing on the types of specific investors and the data that has been used in this research is a secondary data that the possibilities of calculation error could occurred without being controlled and monitored. In addition, this study uses only sector companies listed on the Indonesia Stock Exchange as the research object so it can not represent the whole company's stock activity.

There are some suggestions that need to be considered by the various parties who have an interest in this area, among others Investors need to understand the capital markets thoroughly. Definition of capital markets, the goal, how to invest, as well as how to analyze the possibility of risks that may appeared when making investments. Investors must be precise in sorting and analyzing contained information in the capital market in order to anticipate any risks arising from investment decisions.

For further research, the advice is to enlarge the research environment into other enterprise sectors in order to accurately represent the capital markets and the observation time for the reaction to the announcement can be reflected in the abnormal return and trading volume can be extended.

\section{REFERENCES}

[1] Anoraga, P., \& Pakarti, P. (2001). Pengantar pasar modal. Jakarta: PT. Rineka Cipta.

[2] Boynton, W. C., Johnson, R. N., \& Kell, G. (2003). Modern Auditing.(edisi 7). Jakarta: Erlangga.

[3] Brigham, E. F., \& Houston, J. F. (2001). Manajemen Keuangan. Buku 1 edisi 8. Jakarta: Erlangga.

[4] Chen, K. C., \& Church, B. K. (1992). Default on debt obligations and the issuance of going-concern opinions. Auditing, 11(2), 30.

[5] Hartono, J. (2008). Teori portofolio dan analisis investasi. Edisi Kelima. Yogyakarta: BPFE.

[6] Indonesia, I. A. (2001). Standar profesional akuntan publik: Jakarta: Salemba Empat.

[7] Ittonen, K. (2007). Stock market reaction to going concern audit reports: Further evidence: Working Paper.

[8] Laksitafresti, A., \& LAKSITO, H. (2012). PENGARUH OPINI WAJAR TANPA PENGECUALIAN DENGAN PARAGRAF PENJELAS (WTP-PP) DAN OPINI WAJAR DENGAN PENGECUALIAN (WDP) TERHADAP HARGA SAHAM DAN VOLUME PERDAGANGAN SAHAM (Studi Empiris Pada Perusahaan Manufaktur Yang Terdaftar Di Bursa Efek Indonesia (BEI) Pada Periode 2004-2010). Fakultas Ekonomika dan Bisnis. 
[9] Mariana, N. H. (2011). PENGARUH INFORMASI LABA, TOTAL ARUS KAS, DAN OPINI AUDIT GOING CONCERN TERHADAP HARGA SAHAM PADA PERUSAHAAN MANUFAKTUR YANG TERDAFTAR DI BURSA EFEK INDONESIA PERIODE 2007-2009. SKRIPSI Jurusan Akutansi-Fakultas Ekonomi UM.

[10] Meiden, C. (2012). Pengaruh opini audit terhadap return dan volume perdagangan saham. AKUNTABILITAS, 7(2).

[11] Natapura, C. (2011). Analisis Perilaku Investor Institusional dengan Pendekatan Analytical Hierarchy Process (AHP). BISNIS \& BIROKRASI: Jurnal Ilmu Administrasi dan Organisasi, 16(3).

[12] Publik, I. A. I. K. A. (2001). Standar Profesional Akuntan Publik. Jakarta: Salemba Empat.

[13] Purba, M. P. (2009). Asumsi Going Concern: Suatu Tinjauan Terhadap Dampak Krisis Keuangan atas Opini Audit dan Laporan Keuangan. Yogyakarta: Graha Ilmu.

[14] Sinarwati, N. K. (2011). MENGAPA PERUSAHAAN MENERIMA OPINI AUDIT GOING CONCERN? JINAH (Jurnal Ilmiah Akuntansi dan Humanika), 1(1).

[15] Sugiyono, M. P. K. (2007). Kualitataif dan R\&D, Bandung: Alfabeta, 2010. Sugiyono, Metode Penelitian Kuantitatif kualitatif dan R\&D Bandung: Alfabeta.

[16] Tandelilin, E. (2010). Portofolio dan Investasi teori dan aplikasi. Yogyakarta: Kanisius, 8-9.

[17] Triono, W. P., \& PERBANAS, S. T. I. E. (2010). Pengaruh Faktor Psikologi Terhadap Perilaku Investor dan Jenis Investasi. Skripsi Sarjana. STIE Perbanas Surabaya.

[18] WICAKSONO, A., \& RAHARJA, S. (2011). PENGARUH LAPORAN AUDIT WAJAR TANPA PENGECUALIAN DENGAN PARAGRAF PENJELASAN DAN LAPORAN AUDIT WAJAR DENGAN PENGECUALIAN TERHADAP ABNORMAL RETURN (Studi Empiris Pada Perusahaan Yang Terdaftar $D i B E I)$. Universitas Diponegoro.

[19] Widharatna, A. R. (2011). Reaksi Pasar Terhadap Pengumuman Opini Auditor Wajar Tanpa Pengecualian Dan Wajar Tanpa Pengecualian Dengan Bahasa Penjelas Pada Perusahaan Yang Tergolong LQ 45 Periode Tahun 2006-2007. UNIVERSITAS AIRLANGGA.

[20] Winarto, W. (2014). Reaksi Pasar di Sekitar Tanggal Pengumuman Laporan Audit Wajar Tanpa Pengecualian dengan Paragraf Penjelasan dan Laporan Audit Wajar dengan Pengecualian. Program Studi Akuntansi FEB-UKSWs.

\section{APPENDIX}

\section{Wilcoxon Signed Ranks Test}

\begin{tabular}{|c|c|c|c|c|}
\hline \multicolumn{5}{|c|}{ Ranks } \\
\hline & & $\mathrm{N}$ & Mean Rank & Sum of Ranks \\
\hline \multirow{4}{*}{$\begin{array}{l}\text { Opinions audit issued } \\
\text { Opinions audit issued }\end{array}$} & Negative Ranks & $3^{\mathrm{a}}$ & 3,33 & 10,00 \\
\hline & Positive Ranks & $2^{b}$ & 2,50 & 5,00 \\
\hline & Ties & $0^{\mathrm{c}}$ & & \\
\hline & Total & 5 & & \\
\hline
\end{tabular}

a. Opinions audit issued < Opinions audit issued

b. Opinions audit issued $>$ Opinions audit issued

c. Opinions audit issued $=$ Opinions audit issued

\begin{tabular}{|l|l|}
\hline \multicolumn{2}{|c|}{ Test Statistics $^{\mathbf{a}}$} \\
\hline $\mathrm{Z}$ & Opinions audit issued - Opinions audit issued \\
\hline Asymp. Sig. (2-tailed) &,$- 674^{\mathrm{b}}$ \\
\hline
\end{tabular}

a. Wilcoxon Signed Ranks Test

b. Based on positive ranks.

Citation: Agustina Cahyaning Wibowo. "Analysis of Going Concern Audit Opinion Issuance" International Journal of Managerial Studies and Research (IJMSR), vol 7, no. 12, 2019, pp. 70-75. doi: http://dx.doi.org/10.2 0431/23 49-0349.0712010.

Copyright: (C) 2019 Authors. This is an open-access article distributed under the terms of the Creative Commons Attribution License, which permits unrestricted use, distribution, and reproduction in any medium, provided the original author and source are credited. 